\title{
How to Select Appropriate Plants for Allergic Children
}

\author{
Giannetti A, Gessaroli M, Cipriani F, Gallucci M, Bertelli L and Ricci G* \\ Pediatric Unit, Department of Medical and Surgical Sciences, University of Bologna, Bologna, Italy \\ *Corresponding author: Giampaolo Ricci, Pediatric Unit, Department of Medical and Surgical Sciences, University of \\ Bologna, S. Orsola-Malpighi Hospital, Via Massarenti, 11 - 40138 Bologna, Italy
}

\section{ARTICLE INFO}

Received: 蔧 February 20, 2020

Published: 幽 March 02, 2020

Citation: Giannetti A, Gessaroli M, Cipriani F, Gallucci M, Bertelli L, Ricci G. How to Select Appropriate Plants for Allergic Children. Biomed J Sci \& Tech Res 26(2)-2020. BJSTR. MS.ID.004315.

Abbreviations: AAFA: Asthma and Allergy Foundation of America; CDC: Center for Disease Control; $\mathrm{CO}_{2}$ : Carbon Dioxide; P.p.m: Parts Per Million; OPALS: Ogren Plant Allergy Scale; PCI: Pollen Contribution Index

ABSTRACT

Pollen-related respiratory allergy has a significant impact on global public health, as it involves around one-quarter of the general population. On the other hand, green areas are of pivotal importance in improving the quality of life through a multitude of effects. Therefore, adequately selecting plants for the urban and country landscape represents an important preventive measure to reduce the burden of the disease. This review aims to summarize the characteristics of the allergenic plants and the measures that can be taken to reduce their impact on public health. The degree of allergenicity of plants can be predicted according to various tools, e.g. the Ogren Plant Allergy Scale (OPALS) and the criteria by the American Academy of Allergy, Asthma \& Immunology. In brief, noninvasive, non-toxic, entomophilous plants (i.e. insect-pollinated flowers) should be the preferred ones. Interventions aimed at reducing the impact of pollen allergy should include both a correct selection of plants and simple individual preventive measures. In conclusion, better understanding how pollen-related respiratory allergy impacts on global public health and defining criteria to adequately choose plants for the landscape is of paramount importance to improve quality of life for children and adults with respiratory allergies.
\end{abstract}

Keywords: Allergy; Climate Change; Entomophilous; Landscape; Plants; Pollen

\section{Introduction}

Around $30 \%$ of the world population suffers from allergic pollen-related diseases [1], constituting an important clinical problem for affected individuals and carrying substantial costs for the healthcare system. In Europe, more than 150 million citizens have chronic allergic diseases, implying costs up to 151 billion euros per year [2] for the National Health Services. This is one of the main health issues at present, and will probably worsen exponentially in the next years, as a result of climatic change and growing urbanization, industrialization, and pollution [3]. Green areas are a qualifying element of urban environment and represent an added value, both in terms of health and economics, given its multiple effects [4]: the regulation of the microclimate through increased evaporation and perspiration, the protection from landslides and the control of river banks, and last but not least the possibility of creating a meeting and association area. The amount of green per capita is an important index to define the quality of life in a city. Green can also improve the physical and psychological well-being of people [5]. However, on the other hand, green can have negative effects, as it happens for patients with pollen allergy.
The prevention of respiratory allergic diseases is therefore an important goal and also a challenge for the scientific community. Complex and still inconclusive studies are being carried out aimed at identifying primary and secondary preventive measures [6,7].

An example of primary prevention might be to avoid that a newborn baby with at least one parent with allergy (therefore considered at risk) becomes allergic. An example of secondary prevention might be to prevent symptoms in people who are already sensitized to an allergen. In this latter topic, the characteristics of the environment in which we live, both indoors and outdoors, play an important role. The Asthma and Allergy Foundation of America (AAFA) [8] periodically indicates which cities have the highest pollen load in the different seasons of the year, in order to adopt appropriate preventive measures and therapies. Allergies are the sixth leading cause of chronic disease in the United States according to the Center for Disease Control and Prevention [9] and represent a health cost of 18 billion dollars. The promotion of a "low allergenic charge environment" may not be easily carried on but is not unfeasible. To achieve this goal, it is important to spread the 
knowledge related to the pathogenetic mechanisms of allergy, as well as the life cycle of plants that are most often implied in allergic manifestations [10].

\section{Plants and Pollen}

Pollens in the atmosphere are the key element (male gametophyte) for the reproduction of seed plants. The pollen grain has a protective layer made up of two walls: an external (hexin) and an internal (intin) wall. When the pollen is mature, it is released for pollination and can reach the female part of the flower, carried by the wind (anemophilous plants) or through insects (entomophilous plants), water, birds and other animals [11]. Pollens that can cause allergies in general have some common characteristics [12]:

a. They belong to anemophilous plants,

b. They contain allergenic components that stimulate the immune system of the allergic subject genetically predisposed to produce specific antibodies,

c. They have to be produced in large quantities from plants widespread in the area, and

d. They have to be small and light in order to be carried by the wind at a great distance [13].

The wall of the pollen grains has numerous proteins that allow the recognition of the granule by the female part of the flower. These same proteins are responsible for allergic reactions in genetically predisposed sensitive subjects, acting as antigens and stimulating the immune system to produce antibodies (IgE). When antibodies and antigens meet, chemical mediators are produced, including histamine, triggering the inflammatory process underlying allergic symptoms, e.g. rhinitis, conjunctivitis, asthma [11]. Some plants (monoecious) have male and female flowers on the same plant, others (dioecious) are male or female: the latter, i.e. the dioecious, are the most allergenic. Mosses and ferns produce pollens that propagate in the surrounding environment, unlike conifers (which belong to gymnosperms) and other plants with flowers (angiosperms); the latter produce large quantities of pollen which spread at considerable distances. Plants with flowers or angiosperms can have different morphologies: ancestral magnoliatype flowers, inconspicuous flowers such as Grasses and Ambrosia, complex flowers such as orchids and sunflowers.

A "perfect" plant for allergic people is the one that has male and female parts in the same flower as tulip, poppy, orchid and magnolia [13]. In the anemophilous angiosperm plants often petals and sepals of the flower are absent or vestige only, and the male part is separated from the female; the flowers constitute inflorescences, that is groups of flowers together like oaks, birches and mulberries. A list of main anemophilus plants that cause allergies is shown in Table 1. Finally, it must be remembered that pollution, especially the particles derived from diesel combustion, increases the allergenicity of pollen. A particular mention is deserved by the Grasses, Ambrosia, and the Parietaria as they produce the highest quantity of clinically relevant allergens. The concentration of the various types of pollen in the atmosphere depends above all on the presence and diffusion of the plants on the territory, as well as on some environmental parameters such as wind, humidity, temperature and atmospheric turbulence. Climate change also affects pollen: the increase in temperatures is associated with lengthening and anticipation of the pollen season, the distribution and establishment of pests and contributes with high concentrations of $\mathrm{CO}_{2}$ to the increase in pollen production $[14,15]$.

\section{Grasses}

This family includes about 9,000 species spread all over the world; some are annual because they produce seeds over a year, others are perennial because they live for several years and produce seeds several times. In unfavourable situations, perennials have the aerial part that emerges from the completely dry soil, while the underground stems survive and give rise to new leaves and flowers in the favourable seasons. Grasses adapt to survive in extremely variable climatic conditions. All the cereals belong to the Grasses family, such as wheat, corn, rice and barley, but also other well-known plants such as bermuda grass, sugar cane and bamboo. The vast plains on all continents such as the Asian steppes, the African savannahs, the prairies of North America or the pampas of South America are dominated by the Grasses plants. In urban environments, the grasses, in addition to forming meadows, grow in abandoned lands, along the slopes and at the edges of the roads. Grasses have mostly anemophilic pollination; in fact, only some cultivated species, such as wheat, become self-pollinating and in this case, pollen is released in very low quantities. The grasses continuously produce pollens, some of which are able to bloom depending on the climatic zones - even during autumn and winter. Within the individual species there is a wide variability regarding the flowering period.

\section{Ambrosia}

The genus Ambrosia belongs to the weed flora and is native to North America. Over 40 species are known, of which the most common are Ambrosia artemisiifolia, Ambrosia trifida and Ambrosia coronopifolia. Ambrosia artemisiifolia (in America called ragweed) is the most invasive and causes allergic crisis in the summer. It was imported into Europe in the early twentieth century, with a prevalent interest in the Hungarian plain. It generally reaches a height of $100-150 \mathrm{~cm}$. Pollen is highly allergenic as well as being produced in large quantities: a single plant can produce over a billion pollen grains per season. The pollen grain is small (1525 microns) for which it can be transported for thousands of kilometers. Ambrosia artemisiifolia is today rapidly spreading in urban areas of central-northern Italy; Ambrosia coronopifolia is present in uncultivated land and in rural areas. They are perennial herbs with long creeping woody rhizomes. 


\section{Parietaria}

The genus Parietaria belongs to the Urticaceae family and is typical of temperate and tropical regions. They are annual or perennial herbaceous plants reaching $20-80 \mathrm{~cm}$ of height. The leaves are alternate, simple, entire, often with a cluster of small leaves in their axils. Flowers are produced in clusters of three to many in the leaf axils, and can either be bisexual or both male and female. The fruit is a small dry achene. The term Parietaria stems from the Latin paries, i.e. wall, as it tends to grow onto old walls. Parietaria pollen is the most important cause of pollen allergies in the Mediterranean area, as the plant is common in this region [16]. The Parietaria pollen mean diameter is measured in micrometres and is larger than $10 \mathrm{~mm}$. Thus, the grains generally induce inflammation in the upper airways and bronchi, whereas they cannot reach the terminal bronchioles. A recent study addressing the seasonality of Parietaria pollination found that it lasts 6-7 months on average, with two main peaks during mid-spring and early fall, respectively [17].

\section{Impact of Climate Change on Pollens}

Human activities and industrialization have led to an increase in atmospheric greenhouse gases and climate change. Indeed, $\mathrm{CO}_{2}$ atmospheric concentration has risen from 280 p.p.m. in 1750 to more than 370 p.p.m. in 2002, whereas global average surface temperature has turned up by $0.6^{\circ} \mathrm{C}$ [18]. Projections estimate that $\mathrm{CO}_{2}$ concentration and temperature increase will top at around 541970 p.p.m. and $1.4-5.8^{\circ} \mathrm{C}$ by 2100 [18]. This epochal climate change is exerting a significant impact on aeroallergen-mediated allergy by a multitude of effects, i.e. pollen amount, pollen allergenicity, pollen season, and plant and pollen distribution [19,20]. Two studies found a significant increase in the production of pollen by Ambrosia, paralleled by the rise in $\mathrm{CO}_{2}$ atmospheric concentration

\section{Measures to Reduce the Burden of Allergy}

\section{How to Select Low Allergenic Plants for the Landscape}

Table 1: Main pollen-producing plants. Plants with a higher allergenic potential are in bold characters.

\begin{tabular}{|c|c|c|c|}
\hline Trees & Shrubs & \multicolumn{2}{|c|}{ Grass } \\
\hline $\begin{array}{c}\text { Fir } \\
\text { Maple tree } \\
\text { Birch } \\
\text { Cypress } \\
\text { Cedar } \\
\text { Eucalyptus } \\
\text { Beech tree } \\
\text { Ash tree } \\
\text { Halzenult tree } \\
\text { Walnut tree } \\
\text { Elm tree } \\
\text { Alder } \\
\text { Pine tree } \\
\text { Poplar } \\
\text { Plane tree } \\
\text { Oak tree } \\
\text { Willow } \\
\text { Sycamore } \\
\text { Yew } \\
\text { Olive tree }\end{array}$ & $\begin{array}{c}\text { Hawthorn } \\
\text { Blackberry tree } \\
\text { Juniper } \\
\text { Elder }\end{array}$ & $\begin{array}{c} \\
\text { Oats } \\
\text { Holcus lanatus } \\
\text { Timothy grass } \\
\text { Bermuda grass } \\
\text { Poa } \\
\text { Wheat } \\
\text { Lolium } \\
\text { Dactylis } \\
\text { Barley } \\
\text { Anthoxanthum odoratum } \\
\text { Rye }\end{array}$ & $\begin{array}{c}\text { Wood sorrel } \\
\text { Amaranth } \\
\text { Artemisia } \\
\text { Ambrosia } \\
\text { Chamomile } \\
\text { Chenopodio } \\
\text { Medicago sativa } \\
\text { Chenopodium album } \\
\text { Nettle } \\
\text { Plantain } \\
\text { Parietaria } \\
\text { Sage } \\
\text { Dandelion }\end{array}$ \\
\hline
\end{tabular}

[21,22]. Ahlholm, et al. [23] examined the amount of the pollen allergen Bet v 1 produced by mountain birch (Betula pubescens) grown at two different temperatures and found significantly higher allergenicity for the trees at higher temperature [23]. Two Italian studies reported an earlier start of the pollen season related to a warming in temperature over the years 1981-2000 [24,25]. Last, Kelly, et al. [26] found that the average altitude of the allergenic plants in Southern California increased by $65 \mathrm{~m}$ between 1976 and 2006, thus augmenting pollen production; this shift was attributed to an increase in average surface temperature [26].

\section{How to Define the Allergenicity of a Plant}

Despite all the limitations of a relatively refined stratification, a book published by the botanist Thomas Ogren entitled "The allergy-fighting garden" ranks the potential allergenicity of plants (OPALS Allergy Index Scale) [27]. Plants are categorized from slightly allergenic ( 1 or 2 ) to highly allergenic (9 or 10), based on several factors, such as: the quantity of pollen produced, the power of the pollen, the duration of flowering of the plant, size, gravity and adhesiveness of the pollen grain. Recently the Aerobiology Committee of the American Academy of Allergy, Asthma \& Immunology defined the criteria and modalities on how to choose plants with least allergenic potential [13]. The recommended plants are shown in Tables $2 \& 3$. The list of recommended plants was obtained by combining the data present in the literature $[13,28]$. Another recent tool is the Pollen Contribution Index (PCI), which considers phenology, pollen grain size, species abundance and pollen production and performed well in identifying a small subset of plants responsible for most airborne grass pollen in a Mediterranean region [29]. Further, Damialis et al. have recently reviewed epidemiological studies worldwide on the allergenic properties of airborne pollen from different plant taxa [15]. 
The selection of plants for the landscape can be a difficult task. There are many recommendations on the least allergenic species to choose, depending on whether the climate is dry or wet $(13,30)$. Tables 1-3 show a list of grass and plants to be avoided and chosen, respectively. In case of doubts on a plant which is not mentioned, a simple algorithm can be adopted (Figure 1), illustrating how to proceed. If the plant produces flowers and has an entomophilic reproduction, through insects, it can be a candidate. If it has toxic or infesting actions, it should be abandoned. Then, it should be checked whether it is appropriate for the climatic area and if it is described with low allergenic potential. In case of positive responses, the plant is selected. The fruit trees are for the most part entomophilic, however they need particular attention if inserted in the landscape only for an aesthetic choice; some trees, such as persimmon, lend themselves very well to entering into a landscape architectural project. For the lawn it would be advisable to choose a grass that produces a reduced amount of pollen and that does not need frequent mowing. Examples of low-pollen grass are hybrid varieties, such as Australian ones called Santa Ana and Windsor. An added feature of these hybrid varieties is that they are very drought tolerant, while the downside is that they are very invasive and difficult to remove once planted.

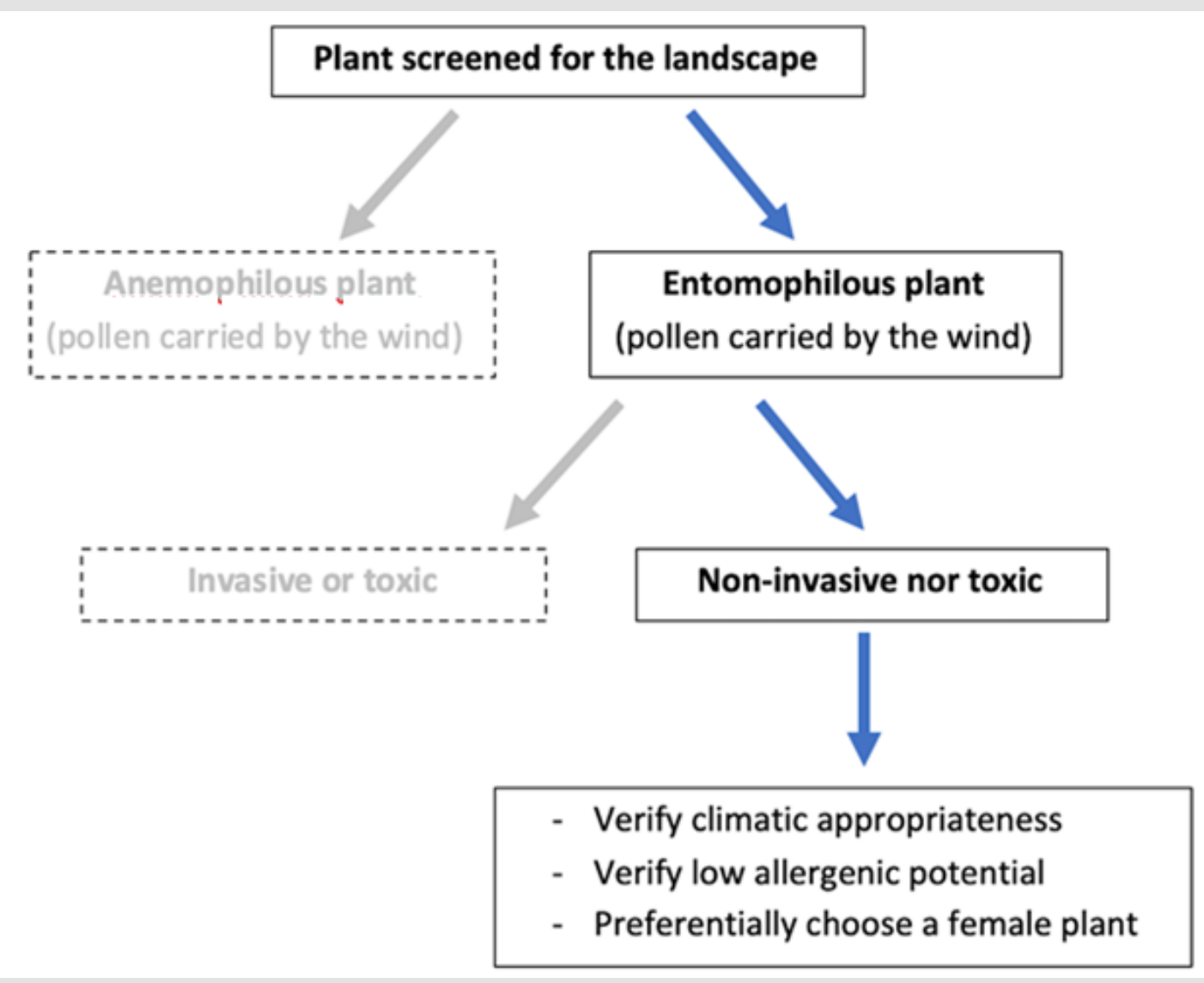

Figure 1: Algorithm for choosing low-allergenic plants for the land scap.

Table 2: Entomophilous tree plants (i.e. insect-pollinated flowers) which can be chosen for a low-allergenic landscape [13,28].

\begin{tabular}{|c|c|c|}
\hline Species & Family & Short Features \\
\hline Ilex opaca & Aquifoliaceae & It is an evergreen tree, belongs to the agrifolio family. The winter buds are brown, short, dull or sharp. \\
\hline Cornus florida & Cornaceae & $\begin{array}{c}\text { It includes shrubs or trees, with deciduous leaves. It is a fairly rustic plant and is used in isolation, in } \\
\text { groups or to form hedges. }\end{array}$ \\
\hline Cornus sanguinea & Cornaceae & $\begin{array}{l}\text { The species spreads by seeds and stolons. Its natural range covers most of Europe and western Asia. It is } \\
\text { especially abundant in riversides, especially in shady areas and ravines. }\end{array}$ \\
\hline Diospyros kaki & Ebenaceae & It is among the oldest cultivated plants, having been in use in China for more than 2000 years. \\
\hline $\begin{array}{l}\text { Diospyros } \\
\text { virginiana }\end{array}$ & Ebenaceae & $\begin{array}{l}\text { The tree grows wild but has been cultivated for its fruits and wood since prehistoric times by Native } \\
\text { Americans. Its fruit is a kind of persimmon. }\end{array}$ \\
\hline Kalmia latifolia & Ericaceae & $\begin{array}{l}\text { Native to North America, where it grows spontaneously in fresh woods, under the foliage of large trees; it } \\
\text { is a magnificent evergreen shrub. }\end{array}$ \\
\hline
\end{tabular}




\begin{tabular}{|c|c|c|}
\hline Baptisia australis & Fabaceae & It is a perennial, attractive green-blue foliage; the flower is blue-lilac, its flowering period is June - August. \\
\hline Sophora japonica & Fabaceae & Deciduous tree with erect bearing, vaguely resembling Robinia, slowly reaches $20 \mathrm{~m}$ in height. \\
\hline Cercis canadensis & Fabaceae & It reaches 11 meters in height, the width is greater than 8 meters, has considerable resistance to cold. \\
\hline Sassafras albidum & Lauraceae & $\begin{array}{l}\text { Sassafras is a shrubby plant common in North America; from the root an essential orange-yellow oil is } \\
\text { obtained. }\end{array}$ \\
\hline $\begin{array}{l}\text { Liriodendron } \\
\text { tulipifera }\end{array}$ & Magnoliaceae & $\begin{array}{l}\text { It is an often multi-stemmed, deciduous tree with a wide spreading, flat topped, rounded, or even spike } \\
\text { shaped open habit. The tree is a popular nesting shrub for songbirds. }\end{array}$ \\
\hline $\begin{array}{l}\text { Magnolia } \\
\text { grandiflora }\end{array}$ & Magnoliaceae & $\begin{array}{l}\text { Although endemic to the lowland subtropical forests on the Gulf and south Atlantic coastal plain, magnolia } \\
\text { grandiflora is widely cultivated in warmer areas around the world. The timber is hard and heavy, and has } \\
\text { been used commercially to make furniture, pallets, and veneer. }\end{array}$ \\
\hline $\begin{array}{l}\text { Liriodendron } \\
\text { tulipifera }\end{array}$ & Magnoliaceae & $\begin{array}{l}\text { The liriodendro or Tulip tree sometimes exceeds } 30 \mathrm{~m} \text { in height with cupped flowers similar to those of } \\
\text { the tulip. }\end{array}$ \\
\hline $\begin{array}{c}\text { Magnolia } \\
\text { soulangeana }\end{array}$ & Magnoliaceae & It is a cultivation hybrid obtained from the French agronomist Soulange-Bodin. \\
\hline $\begin{array}{c}\text { Magnolia } \\
\text { soulangiana }\end{array}$ & Magnoliaceae & $\begin{array}{l}\text { It is a hybrid plant. Its flowers emerge dramatically on a bare tree in early spring, with the deciduous } \\
\text { leaves expanding shortly thereafter, lasting through summer until autumn. }\end{array}$ \\
\hline Magnolia stellata & Magnoliaceae & $\begin{array}{l}\text { The tree blooms at a young age, with the slightly fragran flowers covering the bare plant in late winter or } \\
\text { early spring before the leaves appear. The flowers are star-shaped. }\end{array}$ \\
\hline $\begin{array}{c}\text { Forsythia } \\
\text { viridissima }\end{array}$ & Oleaceae & It is a deciduous Shrub growing to $2.5 \mathrm{~m}$. \\
\hline $\begin{array}{l}\text { Chionanthus } \\
\text { virginicus }\end{array}$ & Oleaceae & $\begin{array}{l}\text { Its name is evocative: it means from the Greek "flower of snow", rustic tree. It does not fear the most } \\
\text { intense frosts, it does not suffer from particular diseases, it is almost never attacked by parasites. }\end{array}$ \\
\hline $\begin{array}{l}\text { Amelanchier } \\
\text { arborea }\end{array}$ & Rosaceae & $\begin{array}{l}\text { Native to North American. The fruit is a berry similar to blueberry, with a sweet taste reminiscent of } \\
\text { gooseberries. }\end{array}$ \\
\hline $\begin{array}{l}\text { Crataegus } \\
\text { monogyna }\end{array}$ & Rosaceae & $\begin{array}{l}\text { It is a species of hawthorn native to Europe, northwest Africa and western Asia. It has been introduced in } \\
\text { many other parts of the world. It can be an invasive weed. }\end{array}$ \\
\hline $\begin{array}{c}\text { Eryobrotrya } \\
\text { japonica }\end{array}$ & Rosaceae & $\begin{array}{c}\text { It is a large evergreen shrub or tree, grown commercially for its yellow fruit, and also cultivated as an } \\
\text { ornamental plant. }\end{array}$ \\
\hline Malus domestica & Rosaceae & It is a deciduous tree that produces apples. \\
\hline Mespilus germanica & Rosaceae & It is a large shrub or small tree, and the name of the fruit of this tree. \\
\hline $\begin{array}{c}\text { Prunus } \\
\text { laurocerasus }\end{array}$ & Rosaceae & $\begin{array}{l}\text { It is an evergreen species of cherry, native to regions bordering the Black Sea in southwestern Asia and } \\
\text { southeastern Europe, from Albania and Bulgaria east through Turkey to the Caucasus Mountains and } \\
\text { northern Iran. }\end{array}$ \\
\hline $\begin{array}{c}\text { Crataegus } \\
\text { phaenopyrum }\end{array}$ & Rosaceae & $\begin{array}{l}\text { It is a species of hawthorn commonly known as Washington hawthorn. It is widely cultivated as an } \\
\text { ornamental plant and can reach } 10 \mathrm{~m} \text { in height. The red berried fruits have a delicate flavor, eaten raw or } \\
\text { cooked. }\end{array}$ \\
\hline Pyrus communis & Rosaceae & $\begin{array}{l}\text { It is a species of pear native to central and eastern Europe and southwest Asia. } \\
\text { It is one of the most important fruits of temperate regions. }\end{array}$ \\
\hline Spiraea vanhuttei & Rosaceae & It is a vase-shaped, deciduous shrub with branching that arches toward the ground. It is a hybrid. \\
\hline
\end{tabular}

Table 3: Entomophilous perennial herbaceous plants (i.e. insect-pollinated flowers) which can be chosen for a low-allergenic landscape $[13,28]$.

\begin{tabular}{|c|c|c|}
\hline Species & Family & Short Features \\
\hline Ilex opaca & Aquifoliaceae & $\begin{array}{c}\text { It is an evergreen tree, belongs to the agrifolio family. The winter buds are brown, short, dull or } \\
\text { sharp. }\end{array}$ \\
\hline Polygonatum odoratum var & Asparagaceae & Perennial herbaceous plant, also called Solomon's seal; present in the woods. \\
\hline Aster tataricus & Asteraceae & $\begin{array}{c}\text { Perennial plant, erect bearing, the flower is light blue purple with a yellow center, its flowering } \\
\text { period is October - November. }\end{array}$ \\
\hline Boltonia asteroides & Asteraceae & $\begin{array}{l}\text { It is a perennial, elongated greyish-green foliage, the flower is white; its flowering period is July } \\
\text { - September. }\end{array}$ \\
\hline Coreopsis verticillata & Asteraceae & $\begin{array}{l}\text { It is a plant with bush development, which can reach } 90 \mathrm{~cm} \text { in height, slowly expanding through } \\
\text { underground rhizomes. The flower head is yellow }\end{array}$ \\
\hline Echinacea purpura & Asteraceae & Perennial plant native to North America with ornamental and herbal interest. \\
\hline $\begin{array}{l}\text { Rudbeckia fulgida var. } \\
\text { sullivantii }\end{array}$ & Asteraceae & Herbaceous plant with typical "daisy” inflorescence. \\
\hline $\begin{array}{l}\text { Symphyotrichum novae- } \\
\text { angliae }\end{array}$ & Asteraceae & Small herbaceous perennial plant; spontaneous. \\
\hline
\end{tabular}




\begin{tabular}{|c|c|c|}
\hline Berberis julianae & Berberidacee & $\begin{array}{l}\text { Native to Central Chine. It is an compact evergreen shrub with rigid, glossy elliptic leaves and } \\
\text { racemes of yellow flowers, tinged with red, in late spring. Bloomy black berries in autumn }\end{array}$ \\
\hline Mahonia acquifolium & Berberidacee & $\begin{array}{l}\text { Native to Western North America. It is an evergreen shrub with pinnate leaves consisting of } \\
\text { spiny leaflets, and dense clusters of yellow flowers in early spring, followed by dark bluish-black } \\
\text { berries }\end{array}$ \\
\hline Radicans tecoma & Bignoniacee & $\begin{array}{l}\text { It is commonly called trumpet vine or trumpet creeper, is a dense, vigorous, multi-stemmed, } \\
\text { deciduous, woody, clinging vine that attaches itself to structures and climbs by aerial rootlets. It } \\
\text { is native to the Southeastern America including Missouri, but has naturalized in many northern } \\
\text { states. }\end{array}$ \\
\hline Lobelia cardinalis & Campanulaceae & $\begin{array}{l}\text { Perennial plant typical of humid places and with beautiful scarlet flowers, it adapts very well to } \\
\text { living in the waters of temperate aquariums. }\end{array}$ \\
\hline Chimonanthus praecox & Calycanthaceae & It is a vigorous deciduous shrub with strongly scented pendent flowers. \\
\hline Viburnum opulus & Caprifoliaceae & $\begin{array}{l}\text { The common name 'guelder rose' relates to the Dutch province of Gelderland, where a popular } \\
\text { cultivar, the snowball tree, supposedly originated. It is a deciduous shrub. }\end{array}$ \\
\hline Viburnum rhytidophyllum & Caprifoliaceae & $\begin{array}{l}\text { It is an evergreen shrub. Produces flat cymes of creamy white flowers in the spring and berries } \\
\text { in early fall which first appear red and then change to a glossy black. }\end{array}$ \\
\hline Viburnum tinus & Caprifoliaceae & $\begin{array}{l}\text { It is a dense, evergreen shrub with dark and oval, glossy leaves, which contrast beautifully with } \\
\text { fragrant pinkish-white flowers, followed by dark black fruit. }\end{array}$ \\
\hline Sedum ternatum & Crassulaceae & Perennial plant with round foliage; the flower is white. \\
\hline Ginkgo biloba & Ginkgoaceae & Native to China, the tree is widely cultivated, and was cultivated early in human history. \\
\hline Lavandula angustifolia & Labiatae & $\begin{array}{l}\text { It is popular for its colourful flowers, its fragrance, and its ability to survive with low water } \\
\text { consumption. }\end{array}$ \\
\hline Rosmarinus officinalis & Labiatae & $\begin{array}{l}\text { It is an aromatic evergreen shrub with leaves similar to hemlock needles. It is native to the } \\
\text { Mediterranean and Asia, but is reasonably hardy in cool climates. }\end{array}$ \\
\hline Caratonia siliqua & Leguminosae & $\begin{array}{l}\text { Native to the Mediterranean region and the Middle Easts, it is widely cultivated for its edible } \\
\text { pods, and as an ornamental tree in gardens and landscapes. }\end{array}$ \\
\hline Cercis siliquastrum & Leguminosae & $\begin{array}{l}\text { It is commonly known as the Judas tree or Judas-tree,is a small deciduous tree from Southern } \\
\text { Europe and Western Asia which is noted for its prolific display of deep pink flowers in spring. }\end{array}$ \\
\hline Gleditsia triacanthos & Leguminosae & $\begin{array}{l}\text { It is a deciduous tree, native to central North America where it is mostly found in the moist soil } \\
\text { of river valleys. }\end{array}$ \\
\hline Sophora japonica & Leguminosae & $\begin{array}{l}\text { It is native to China; despite the name, it was introduced in Japan. It is a popular ornamental tree } \\
\text { in Europe, North America and South Africa, grown for its white flowers, borne in late summer } \\
\text { after most other flowering trees have long finished flowering. }\end{array}$ \\
\hline Lagerstroemia indica & Lythraceae & It is a very popular flowering shrub/small tree in mild-winter states. \\
\hline Hibiscus syriacus & Malvaceae & $\begin{array}{l}\text { It is a hardy deciduous shrub. It is upright and vase-shaped, bearing large trumpet-shaped } \\
\text { flowers with prominent yellow-tipped white stamens. }\end{array}$ \\
\hline Ficus carica & Moraceae & It is an Asian species of flowering plant in the mulberry family, known as the common fig. \\
\hline Maclura pomifera & Moraceae & $\begin{array}{l}\text { It is a small deciduous tree or large shrub, The fruits secrete a sticky white latex when cut or } \\
\text { damaged. }\end{array}$ \\
\hline Musa basjoo & Musaceae & $\begin{array}{c}\text { It is a herbaceous perennial. The species produces male and female flowers on the same } \\
\text { inflorescence which may extend for over } 1 \mathrm{~m} .\end{array}$ \\
\hline Trachycarpusa fortunei & Palmae & It is a species of hardy evergreen palm tree. \\
\hline Penstemon digitalis & Plantaginaceae & Evergreen perennial plant, beautiful large foliage, slightly wavy; the flower is white. \\
\hline Phlox divaricate & Polemoniaceae & $\begin{array}{l}\text { Plants native to America and Asia. The herbaceous stem ends with numerous tubular flowers, } \\
\text { variously colored and speckled, of great decorative effect. }\end{array}$ \\
\hline Punica granatum & Punicaceae & $\begin{array}{l}\text { It is a fruit-bearing deciduous shrub. It is grown for its fruit crop, and as ornamental trees and } \\
\text { shrubs in parks and gardens. Mature specimens can develop sculptural twisted-bark multiple } \\
\text { trunks and a distinctive overall form. }\end{array}$ \\
\hline Helleborus orientalis & Ranuncolaceae & $\begin{array}{l}\text { It is also called Christmas Rose, because it blooms between December and February, as soon as } \\
\text { warm days occur during the winter. }\end{array}$ \\
\hline Heuchera micrantha & Saxifragaceae & $\begin{array}{l}\text { Evergreen with beautiful lobed leaves and erect racemes of small tubular flowers. It is mainly } \\
\text { cultivated for highly ornamental foliage throughout the whole year. }\end{array}$ \\
\hline Paulownia tomentosa & Scrophulariaceae & $\begin{array}{c}\text { It is an extremely fast-growing deciduous tree, and is a persistent exotic invasive in North } \\
\text { America. }\end{array}$ \\
\hline Tamarix gallica & Tamaricaceae & It is a deciduous, herbaceous, twiggy shrub or small tree reaching up to about 5 meters high. \\
\hline
\end{tabular}




\section{Other Measures to be Taken}

Other practical advice can be suggested to facilitate the creation of a low allergenic load landscape and can be summarized in the following proposals:

a) If you are interested in planting an anemophilous dioecious plant, it would be advisable to choose the female one, which does not produce pollen.

b) If there is a male plant in the garden and it is not possible to remove it, we recommend planting a female plant near it, which will capture part of the male pollen.

c) A strong annual pruning can reduce the pollen load produced by a male tree. In fact, most trees with high allergenic load such as birches and alders have male cones at the ends, so that pruning the tops by $15-20 \mathrm{~cm}$ in autumn will reduce the pollen load in the following spring.

d) To reduce the pollen load in your area, you can create a hedge on the borders with female plants.

For example, in warm regions where Pitirosporum is present, the planting of a female hedge of Pitirosporum will capture many male pollens; a yew hedge in colder climates can perform the same function. For meadows it is important to arrange frequent mowing to prevent the grass from developing inflorescences: knowing that in a region in general the flowering of grasses plants usually begins in April, cutting the lawn in mid-March and soon repeating the cut prevents the plant from producing pollen. Finally, do not forget to weed out the weeds, especially Ambrosia and to constantly remove the Parietaria. Furthermore, it is necessary to consult the regional/ national Bulletin of pollen and spore in order to monitor the local trend of allergens. Patients with known pollen allergy should follow preventive measures, such as

a. Limiting outdoor activities when pollen counts are high,

b. Keeping windows closed during pollen season,

c. Bathing and shampooing their hair daily before going to bed,

d. Washing bedding in hot, soapy water once a week,

e. Wear sunglasses and a hat when outdoor, and

f. Changing and washing clothes worn during outdoor activities.

\section{Conclusion}

Allergic diseases are constantly increasing so all the possible measures must be implemented to reduce their clinical potential, intervening at every level $[3,13,30]$. When addressing the issue of environmental green, both private and public, one must first think of creating a collective culture. It is therefore necessary to integrate information: a. You need to know which plants are present in the territory with a listing of the existing species.

b. You must consult the Bulletin of pollen and allergenic spores.

c. It is necessary to inform and train those who deal with the management of public green spaces, but also to transmit information to private individuals who still manage a relevant aspect. In this sense, botanical and biological, but also clinical knowledge can help change some habit and some landscape habitats without giving up on having a pleasant and soothing green environment.

The adoption of simple methods to choose the type of plants to be planted can significantly help block the increase in allergic diseases or at least contain its symptoms. The planning of these interventions must be the task of the public structure which must coordinate the measures and favour a culture where the private sector must and can be an important force.

\section{Key Messages}

- $\quad$ Allergic pollen-related diseases have a high worldwide prevalence and imply substantial healthcare costs.

- Air pollution and climate change related to industrialization and urbanization contribute to increase pollen allergenicity and sensitization.

- $\quad$ Green areas have multiple positive effects on people's health; on the other hand, they carry an important allergenic load.

- A list of species with the highest and least allergenic potential is provided in order to better choose plants for the landscape.

- Hints to reduce pollen spread in the atmosphere are:

a. Choose entomophilous species or the female gender of anemophilous dioecious plant.

b. Plant female plants near the male ones, in order to capture pollens.

c. Periodically prune male trees such as birches and alders.

d. Create a hedge on the borders with female plants.

- $\quad$ Pollen calendars are useful tools showing the peak pollen times for various plants in different areas.

\section{References}

1. Pawankar R (2014) Allergic diseases and asthma: A global public health concern and a call to action. World Allergy Organ J 19(7): 12.

2. Zuberbier T, Lötvall J, Simoens S, Subramanian SV, Church MK (2014) Economic burden of inadequate management of allergic diseases in the European Union: A GA (2) LEN review. Allergy 69(10): 1275-1279. 
3. Cecchi L, D'Amato G, Ayres JG, Galan C, Forastiere F, et al. (2010) Projections of the effects of climate change on allergic asthma: The contribution of aerobiology. Allergy 65(9): 1073-1081.

4. Braubach M, Egorov A, Mudu P, Wolf T, Ward Thompson C, et al. (2017) Effects of Urban Green Space on Environmental Health, Equity and Resilience. In: Kabisch N, Korn H, Stadler J, Bonn A (Eds.)., NatureBased Solutions to Climate Change Adaptation in Urban Areas: Linkages between Science, Policy and Practice [Internet]. Cham: Springer International Publishing pp. 187-205.

5. Chiesura A (2004) The role of urban parks for the sustainable city. Landsc Urban Plan 68(1): 129-138.

6. Cilluffo G, Ferrante G, Fasola S, Montalbano L, Malizia V, et al. (2018) Associations of greenness, greyness and air pollution exposure with children's health: a cross-sectional study in Southern Italy. Environ Health 17(1): 86

7. Cariñanos P, Grilo F, Pinho P, Casares Porcel M, Branquinho $\mathrm{C}$, et al (2019) Estimation of the Allergenic Potential of Urban Trees and Urban Parks: Towards the Healthy Design of Urban Green Spaces of the Future. Int J Environ Res Public Health 16(8).

8. Asthma and Allergy Foundation of America | AAFA.

9. (2019) Climate Change and Public Health - Health Effects - Allergens CDC.

10. D'Amato G, Liccardi G, D'Amato M, Cazzola M (2001) The role of outdoor air pollution and climatic changes on the rising trends in respiratory allergy. Respir Med 95(7): 606-611.

11. Cignini B, Albani L, Ragonese A, Diamanti S, Adamo B, et al. (2017) Linee guida per la gestione del verde urbano e prime indicazioni per una pianificazione sostenibile.

12. D’Amato G, Cecchi L, Bonini S, Nunes C, Annesi Maesano I, et al. (2007) Allergenic pollen and pollen allergy in Europe. Allergy 62(9): 976-990.

13. Green BJ, Levetin E, Horner WE, Codina R, Barnes CS, et al. (2018) Landscape Plant Selection Criteria for the Allergic Patient. J Allergy Clin Immunol Pract 6(6): 1869-1876.

14. Albertine JM, Manning WJ, Da Costa M, Stinson KA, Muilenberg ML, et al. (2014) Projected Carbon Dioxide to Increase Grass Pollen and Allergen Exposure Despite Higher Ozone Levels. PLoS ONE 9(11)

15. Damialis A, Traidl Hoffmann C, Treudler R (2019) Climate Change and Pollen Allergies. In: Marselle MR, Stadler J, Korn H, Irvine KN, Bonn A (Eds.)., Biodiversity and Health in the Face of Climate Change [Internet] Cham: Springer International Publishing p. 47-66.

16. Ciprandi G, Puccinelli P, Incorvaia C, Masieri S (2018) Parietaria Allergy: An Intriguing Challenge for the Allergist. Med Kaunas Lith 54(6): 106.

\section{ISSN: 2574-1241}

DOI: $10.26717 / B J S T R .2020 .26 .004315$

Ricci G. Biomed J Sci \& Tech Res

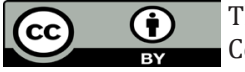

This work is licensed under Creative

Commons Attribution 4.0 License

Submission Link: https://biomedres.us/submit-manuscript.php
17. Ariano R, Cecchi L, Voltolini S, Quercia O, Scopano E, et al. (2017) Parietaria pollination duration: myth or fact? Eur Ann Allergy Clin Immunol 49(1): 6-10.

18. Prentice I, Farquhar G, Fasham M, Goulden M, Heimann M, et al. (2001) The carbon cycle and atmospheric carbon dioxide. In: Houghton JT, Ding Y, Griggs DJ, Noguer M, Linden PJ van der, et al. (Eds.)., Climate Change 2001: The Scientific Basis. Cambridge University Press pp. 183-237.

19. D’Amato G, Holgate ST, Pawankar R, Ledford DK, Cecchi L, et al. (2015) Meteorological conditions, climate change, new emerging factors, and asthma and related allergic disorders. A statement of the World Allergy Organization. World Allergy Organ J 8(1): 25.

20. Beggs PJ (2004) Impacts of climate change on aeroallergens: Past and future. Clin Exp Allergy J Br Soc Allergy Clin Immunol 34(10): 15071513

21.Ziska LH, Caulfield FA (2000) Rising CO2 and pollen production of common ragweed (Ambrosia artemisiifolia L.), a known allergy-inducing species: implications for public health. Funct Plant Biol 27(10): 893-898.

22. Wayne P, Foster S, Connolly J, Bazzaz F, Epstein P (2002) Production of allergenic pollen by ragweed (Ambrosia artemisiifolia L.) is increased in CO2-enriched atmospheres. Ann Allergy Asthma Immunol Off Publ Am Coll Allergy Asthma Immunol 88(3): 279-282.

23. Ahlholm JU, Helander ML, Savolainen J (1998) Genetic and environmental factors affecting the allergenicity of birch (Betula pubescens ssp. czerepanovii [Orl.] Hämet-ahti) pollen. Clin Exp Allergy J Br Soc Allergy Clin Immunol 28(11): 1384-1388.

24. Frenguelli $G$ (2002) Interactions between climatic changes and allergenic plants. Monaldi Arch Chest Dis Arch Monaldi Mal Torace 57(2): 141-143.

25. D’Amato G, Liccardi G, D’Amato M, Cazzola M (2002) Outdoor air pollution, climatic changes and allergic bronchial asthma. Eur Respir J 20(3): 763-776

26. Kelly AE, Goulden ML (2008) Rapid shifts in plant distribution with recent climate change. Proc Natl Acad Sci USA 105(33): 11823-11826.

27. The Allergy-Fighting Garden by Thomas Leo Ogren. Penguin Random House.

28. Lorenzoni Chiesura F, Giorato M, Marcer G (2000) Allergy to pollen of urban cultivated plants. Aerobiologia 16: 313-316.

29. Romero Morte J, Rojo J, Rivero R, Fernández González F, Pérez Badia R (2018) Standardised index for measuring atmospheric grass-pollen emission. Sci Total Environ 612: 180-191.

30. Cariñanos P, Casares Porcel M (2011) Urban green zones and related pollen allergy : A review. Some guidelines for designing spaces with low allergy impact. Landsc Urban Plan 101(3): 205-214.

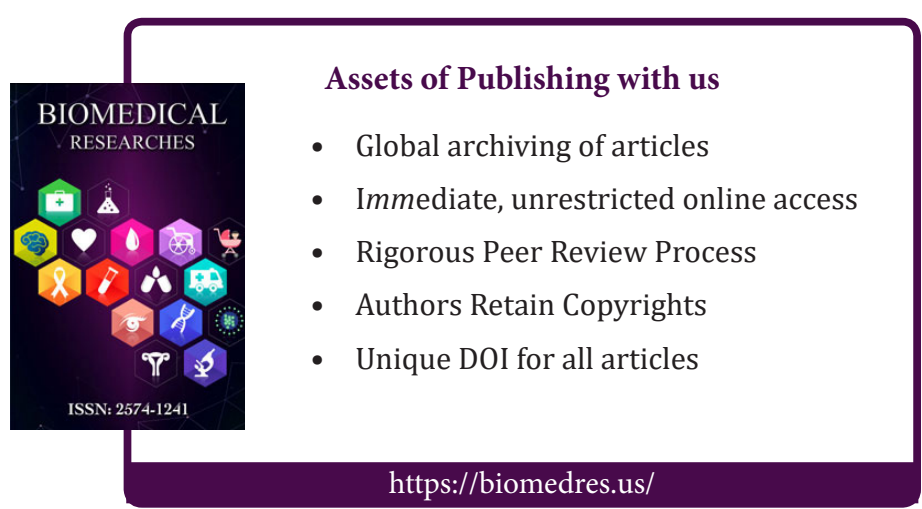

